\title{
SOURCES OF DOUBT, SOURCES OF DUTY: HLA HART ON \\ INTERNATIONAL LAW
}

\author{
JOHN R MORSS
}

\begin{abstract}
[In many ways HLA Hart's critical analysis of the concept of law, with its repudiation of simple command theories of legal obligation, is at the same time a critique of the notion of state sovereignty. It is therefore an adumbration, if no more, of a radical reconceptualisation of international law, one which redefines the distinction between municipal and international jurisdiction. This paper is an exploration of what Hart could or 'should' have said about international law, based as much as possible on what he did say about international law and law in general. After some introductory comments it outlines Hart's general analysis of law, with particular reference to the relevance for our understanding of international law.]
\end{abstract}

\section{INTRODUCTION}

In The Concept of Law and elsewhere, Hart comprehensively demolished the portrayal of law as being constituted by coercion or command by a law-giver who is himself untouched by law - by an 'unmoved mover' as it were. Hart showed that

\footnotetext{
*Associate Head, Deakin Law School. E-mail: john.morss@deakin.edu.au. The paper was first presented at the Annual Conference of the Australian Society of Legal Philosophy, 2004 and I acknowledge the helpful comments of several colleagues who attended. I also thank James Allan for teaching me my Hart at the University of Otago, and William Twining for generous comments on the present project. This paper is part of a larger project in the reconceptualisation of international law, being conducted with Mirko Bagaric whose encouragement I would also like to acknowledge.
} 
this is no more than a myth (and no more true, in all probability, in 'primitive' societies than in modern ones). Now it is the sovereign state which most exemplifies that myth, with its portrayal of distinct polities each ruled by either a king or queen, or by some entity that embodies the power of a monarch. The sovereign state (as legal entity) therefore seems to collapse under Hart's critique. Yet it has been central to the worldview of classic international law (IL), and it still remains unclear whether IL without the sovereign state has any future. ${ }^{1}$

This proposal, as representing Hart's contribution, may seem to go well beyond Hart's own accounts of IL. ${ }^{2}$ Hart mentions international law on several occasions in the main body of The Concept of Law, as well as devoting a chapter to some (narrow) aspects of it therein, ${ }^{3}$ but does not expressly endorse or even indicate such sweeping consequences. Yet Hart must have been (as a politically committed legal theorist) very aware that the Cold War, so defining a feature of the post-War world in which he was writing, had eradicated any meaningful notion of separate sovereign states in Europe or the wider world. The notion of sovereign state, in which every state is conceptually equal as if so many atoms or Olympics teams, hardly bore scrutiny in the case of the eastern European countries dominated by the USSR. The USSR itself, and the USA, were very much more than merely two of many distinct states on the face of the globe. Geopolitical reality comprised two armed camps with satellites and other dominated territories. And even without considering the Cold War as such, the Security Council's structure of permanent and vetoendowed members, ensuring dominance of the military victors of World War II strikingly illustrated the obsolescence of the classical, state-as-atom account.

\section{HART'S GENERAL ANALYSIS}

Law is not, and probably has never been, simply a matter of someone saying "I am King - I make the laws - obey me or else.” There certainly have been monarchs, and other persons with temporary political power over others, who have attempted to redefine law as being constituted by their will. England's (and indeed Scotland's) Charles I famously attempted this, forgetting the fact that monarchs of England had historically been merely first among equals, representing a class or caste perhaps but by no means God-like in legislative power. Emperors (and Dowager Empresses) of the Middle Kingdom most certainly understood that law emanated from their person and in some epochs, that their edicts were binding on the whole world. ${ }^{4}$

\footnotetext{
${ }^{1}$ Mirko Bagaric and John R MoRss, CONTEMPorary IsSUES In InTERNATIONAL LAW (in press, 2006); see also John R Morss, Heteronomy as the Challenge to Nation: A Critique of Collective and of Individual Rights, 8 LAW, TEXT, CULTURE 167 (2004).

${ }^{2}$ HLA HART, Self-Referring Laws; American Jurisprudence through English Eyes: The Nightmare and the Noble Dream; Kelsen's Doctrine of the Unity of Law, all in HLA HART, ESSAYS IN JURISPRUDENCE AND PHILOSOPHY (1983).

${ }^{3}$ HLA HART, THE CONCEPT OF LAW ch 10 (1961).

${ }^{4}$ Randall Peerenboom, China's Long March Toward Rule of Law China's Long March TOWARD RULE OF LAW 37 (2002).
} 
But the issue is not really historical or empirical. Rather, laws are rule-bound obligations, serving as much to enable legal relationships to be voluntarily assumed by people as to coerce them. Hart's general analysis thus focused on the inadequacies of the command theory of legal obligation, according to which law arises and maintains its validity only through the coercive diktats of an unruled ruler. Hart showed that the command theory does not work. To make sense of what we in everyday ways understand by legal obligation and legal conduct, we have to recognize that law is defined by procedure rather than by the origin of legal pronouncements as such. Even if we have a constitutional monarchy, in which King Fred- or Queen Edna-in-Parliament constitutes the sovereign, it is the procedural matrix in which their words and actions are embedded that make what they say or do 'law' and give rise to obligations in others and (at least in principle) in themselves.

Thus any lawfulness we observe (or think we observe) at an international level cannot, on Hart's analysis, be explained by the action of sovereigns. So what form of explanation might there be? Hart assists us at least by clarifying this question. The question of whether there is any such thing as lawfulness (legal obligation) even in the domestic realm is of course necessarily moot for Hart. Hart has to place in suspension (or as it were in brackets) any definitive sense of the legal either intensive or extensive, because his aim is to start from scratch with the conceptual definition. He cannot presuppose that any particular event or practice $\mathrm{X}$ is an example of legal obligation, any more than he can presuppose any definition of the legal. Hart tosses our understanding of the legal up in the air, pending his discussion.

Some sleight of hand is perhaps necessarily involved. When 'the legal' falls to earth, now in its Hartian guise, it must bear some resemblance to our intuitions while Hart will have failed if intuition could have led us direct to that account. Hart thus needs to persuade us that that for which he has provided an analysis indeed corresponds to what we thought it was and for which he was seeking to provide the superior explanation. We must in some manner recognize the place Hart brings us to, although our recognition may be a Wittgensteinian family-resemblance process rather than an absolute reaffirmation of a stable identity. If after reading The Concept of Law we return to exactly the place from which we started it, Hart will again have failed.

Hart therefore suspends the empirical question of 'does legal obligation exist?' in order more comprehensively to re-define the conceptual nature of legal obligation in effect comprehensively to examine what we mean when we use that form of words. Therefore when Hart discusses the question of whether legal obligation exists in the international arena (as he does at some but not great length in his Chapter X of The Concept of Law) this should not be seen as a question that is in significant ways unique to the international dimension. For Hart the existence of legal obligation is emphatically not so to speak 'the problem of international law' the litmus test which any new account must pass to be accepted.

This important point must be stressed. For Hart repudiates the orthodox duality by which domestic lawfulness is unproblematic in principle (unproblematic because under the orthodoxy, it derives from and is explained by the command of a sover- 
eign) and international lawfulness problematic in principle (because of the supposed and correlative absence of proper command in the international sphere). For Hart to endorse this orthodox dichotomy would of course be for him to undermine his entire enterprise. Therefore, even though Hart may appear to treat international law in just this orthodox way in his Chapter X of The Concept of Law - worrying about its obligation-generating basis - it would be illogical for him to have done so. We must look more carefully into Hart's scattered claims relating to IL and perhaps more significantly, into the implications for IL of his wider claims.

What then does Hart tell us (albeit indirectly for the most part) about how to conceive of IL? As noted above, he puts in suspension any definite conclusion about what might count as legal obligation beyond the borders; but while this looks like mere endorsement of orthodoxy, in fact this is in a deeper sense, significantly consistent with his general approach. Hart would surely concede that the actions of the International Court of Justice constitute some kind of ostensibly legal process at least prima facie, in the same way that examples within the municipality serve the same function. There is at least roughly speaking, as much reason to say that legal obligation exists internationally as to say that it exists domestically.

Having made that tentative and hypothetical assertion, Hart in fact stops his discussion but the consequences seem clear because Hart has already explored the same issues in the domestic sphere, in chapters I through IX of The Concept of Law, and we can extrapolate. All we have to do therefore is to follow through on Hart's procedure, being careful not to slip back into the orthodox dichotomy. Above all Hart tells us that legal obligation is indivisible conceptually at the same time as it has infinite diversity in an empirical sense. Legal obligation is a matter of highlevel rule-boundness of conduct, that is to say matters of procedure which are not rooted in commands. These days it may be tempting to say 'practice' or even 'discourse' instead of procedure, however Hart would undoubtedly be wary of becoming too relativistic.

The insistence on procedure as the essence of lawfulness seems unfamiliar as an account of Hart. It is Hart's emphasis on the rule-boundness of law that is more patent. But rule and procedure are different ways of saying the same thing. It might for example be suggested that a procedural analysis of legal obligation necessarily involves both 'primary' and 'secondary' levels of rule, that is to say both 'obligations' and 'rules of recognition.' The duality of Hart's account is central to it - only the combination of primary and secondary rules can explain what Hart seeks to explain, if a rule-framed account is being employed. However the term 'procedure' would seem to cover both the elements and their interactions. What stands out is that both a rule analysis and a procedure analysis reject the view that legal obligation is defined by the source of a statement as such. As Hart put it, the "key to the science of jurisprudence" is not command but fundamentally accepted rules "specifying the essential lawmaking procedures." 5 In some respects the definition is circular, so that for Hart, one can say little more but that law is law. This is not

\footnotetext{
${ }^{5}$ HLA Hart, Positivism and the Separation of Law and Morals, 71 HARV. L. REV. 593 (1958).
} 
(quite) mere tautology although it is an exceedingly 'thin' ${ }^{6}$ approach, asymptoting towards tautology perhaps, in a Wittgensteinian way, where more traditional positivism would be slightly further from tautology (hence somewhat 'thick') and natural law further still (even thicker).

Hart was certainly aware that recognition (as he defines it) raises serious difficulties in relation to IL. Given the decentralization of IL, "certain problems in defining what constitutes sufficient recognition will have to be faced." ${ }^{7}$ However some tentative concluding remarks can be made.

\section{INTERNATIONAL LAW AFTER HART}

In many ways the effect of Hart's demolition of the command theory is to demolish with it the distinction between domestic and international law. It is not that Hart ignores the fact that an English law against witchcraft (for example) will generally not be a law in France even though it may persist in England for many centuries after its promulgation. This is more a matter of what is often called 'conflict of laws' (or comparative law), usually thought of as a poor and humble cousin of IL in terms of jurisprudence, and it might be said that Hart's analysis reduces all international law to that. ${ }^{8}$

Hart's dissolution of the boundaries between domestic (within-state) and international (between-states) legal domains means that legal supremacy must be defined in such a way as to distinguish it from a simple command analysis. In the United States for example there is a genuine and significant supremacy residing in the Constitution, especially as implemented by the Supreme Court, such that parliamentary-style (Congress) decisions may be overturned. ${ }^{9}$ Hart therefore recognizes that local (territory-based) supremacies indeed exist, but this procedural contingency is far from giving rise to the command-type situation on which classical IL centres.

Indeed in 1796 it was held that on declaring its independence two decades before, the USA was "bound to receive the law of nations, in its modern state of purity and refinement." 10 This law was taken to comprise three components: the (positive) norms governing relations between states - seen as an extra-judicial domain; a set of quasi-Common Law rules, admitting of judicial remedies, relating to the "conduct of individuals situated outside domestic boundaries"11 - conduct relating to such mercantile issues as prizes, shipwrecks, and hostages; and finally a hybrid

\footnotetext{
${ }^{6}$ The vocabulary derives from anthropologist Clifford Geertz. In the context of the advocacy of a 'thick' approach (to Rule of Law in the People's Republic of China), 'thin' means merely procedural: PEERENBOOM, supra note 4, at 65.

${ }^{7}$ Hart, Kelsen's Doctrine, supra note 2, at 340; also see Hart, 'Problems of recognition', Id. at 339-42.

${ }^{8}$ Hart affirms the practical importance of nation-state boundaries: Id at 336.

${ }^{9}$ Hart, The Nightmare and the Noble Dream, supra note 2.

${ }^{10}$ Ware v Hylton, 3 Dall. 199, 281 (1796) (Wilson, J), cited in Sosa v Alvarez-Machain (03-339) 331

F.3d 604 (2004) (US Supreme Court) (Souter J).

${ }^{11}$ Sosa v Alvarez-Machain (03-339) 331 F.3d 604 (2004) (US Supreme Court) (Souter J).
} 
sphere including such offenses as piracy, violation of safe conducts and infringements of the rights of ambassadors, which also admitted of judicial remedies. This last thus concerned conduct arising directly from the actions of individuals but having implications for the harmony or otherwise of state-state relations.

Thus the US Supreme Court, charged with implementing the Constitution among other things, has continually 'framed' and re-framed its attitude to legal expectations and obligations deriving from outside the United States (thus 'alien'), including international conventions on human rights and the decisions of bodies such as European Courts. For example, in 2005 international opinion against the death penalty for juveniles 'provide[d] respected and significant confirmation for the Court's determination that the penalty is disproportionate punishment for offenders under 18. ${ }^{12}$ In effect overseas law (converging with other considerations) influenced the Supreme Court in its decision to re-interpret the position of the US Constitution on the death penalty for minors, thus reversing the position it had taken as recently as $1989 .{ }^{13}$ It is of course consistent that US courts may authorize federal civil suits against foreign states for relief in personam in those situations where no sovereign immunity is recognized. ${ }^{14}$ Sovereign immunity for a foreign government is thus a special factor canceling out the default circumstance by which relief may be sought, ie the default circumstance involves the implementation overseas of US law.

There is therefore - to justify and to give meaning to the Supreme Court's deliberations on these matters - a fluidity here, a permeability of the supposedly watertight state boundaries. If the 'alien' decisions and instruments had no possibility of meaningfulness within US law - if there were no way that they could influence the latter, even if admitted - then the USSC's peregrinations would be otiose. As in JRR Tolkien's formulation of another matter, it would be as if a 'No Smoking' sign were displayed in a country ignorant of tobacco. It is only because the alien decisions might have an effect (be meaningful as law) locally that the issue of whether or not they shall be admitted, is an issue for the USSC. Thus there must be some epistemic compatibility - in some sense the alien and the US laws must be of the same category, or of the same level. This account might seem to be inching towards a Kelsenian seamlessness of law, ${ }^{15}$ but Hart's position is distinct from that.

Similarly, Hart would surely have recognized international commercial arbitration for example as just as much 'legal' as the ruminations of the International Court of Justice. Under Hart's analysis therefore, traditional distinctions between 'public' and 'private' International Law seem also to evaporate. It may well be that the study of international commercial arbitration would be more informative and illu-

\footnotetext{
${ }^{12}$ Roper, Superintendent, Potosi Correctional Center v Simmons, (03-633) 112 S.W. 3d 397 (2005) (US Supreme Court) (Syllabus) (affirming the view of the Missouri Supreme Court).

${ }^{13}$ Stanford v Kentucky, 492 US 361 (1989) (US Supreme Court).

${ }^{14}$ Republic of Austria et al. v Altmann, (03-13) 327 F.3d 1246 (2004) (US Supreme Court). Respondent Altmann claimed that Austria held art works seized illegally from a family member during the Nazi regime or shortly after World War II.

${ }^{15}$ Hart, Kelsen's Doctrine, supra note 2, at 315.
} 
minating than the study of 'public' International Law. The distinctions certainly need to be re-examined. At least in non-legal senses, the private and the public in international relations seems to have fallen an early victim to globalization.

Also quite generally, we can say that IL is a rule-bound (procedural) enterprise; that it is no less law than either modern/municipal or 'primitive' law; and that it has no more connection with sovereigns than they do. It provides the resources with which voluntary legal relations can be established. But between whom or what? If this means treaties, we seem still to be making orthodox assumptions about a class/category issue in terms of the subjects of law: states versus individuals. In suggesting that IL be thought of exactly as any other law, there may appear to be the likelihood of a category error (or something similar to that) - ie a fundamental, logical mistake about compatibility, such as we might accuse a beginning student of making ("you just don't yet understand what public international law is") . The distinction seems to be one between individuals (as subjects of domestic laws) versus certain classes of individuals, viz states (as subjects of international laws).

Hart's approach allows us to escape this apparent logical difficulty. First, Hart's position on municipal law is not individualistic, partly in that it departs from command theory which is individualistic in several ways. Hart seems to be talking (in general) about rule-bound procedures affecting the conduct of groups or communities of people, rather than individuals as such. Therefore, it may be possible to break down or at least sidestep the 'individual-State' dichotomy insofar as it refers to a logical matter of classes or categories.

It may be possible, following Hart, to articulate a description of 'International Law' that is not superordinate to 'municipal law' as in the orthodox account but rather, is somehow at the same level - as it were 'across.' For example classic international law issues like invasions of one country by another, are as well as being governmental-relationship issues (ie issues between Executives), issues of groups of people eg armed forces, doing certain things. It is not unusual for such activities to be regulated within a state, also in ways that are not entirely individualized, so that it is not the conduct itself which requires a qualitatively different form of legal analysis when it involves inter-national conflict.

Again, individualized (criminal or quasi-criminal) responsibility is sometimes available outside the municipal, eg in terms of crimes against humanity (and while greatly expanded in recent decades, this is not a new phenomenon since piracy has long been treated in this manner). If we are interested in the individual level strictly defined (as it were, the habeus corpus level), international law is only occasionally so concerned. But this is also the case for municipal law. A dichotomy of individual-collective does not map neatly on to a dichotomy municipal-international. In Hart's words, the dichotomy according to which IL imposes obligations on states, and municipal law imposes obligations on individuals, is "crude and misleading." 16

\footnotetext{
${ }^{16}$ Id. at 314 (also at 315, “crude and confused”).
} 
Collective culpability of a firm, for another example, may be available municipally. International law, especially of a commercial kind, also in various ways, provides for culpability of enterprises. We could treat States as kinds of firm, stable enterprises that can acquire obligations to individuals or to other firms, public or private. The point again is to bring the actions of States into the generic Hartean melting-pot of legal obligation, denying to States the opportunity of remaining aloof from the hurly-burly: ie we erase the special status of the State as legal subject.

To continue this line of thinking, treaties may be thought of as equivalent to industry regulation of firms, perhaps equivalent to codes of practice to which they voluntarily adhere; these do have a genuine but limited voluntary quality although clearly there are 'market forces' encouraging all firms in an industry to sign up to certain industry norms. Yet another possible model for the international agreement is the Customary International Law (CIL). According to the orthodoxy, CIL is discovered or identified on the basis of a strange combination of widespread state conduct and the protean opinio juris sive necessitatis - the sense of (international) obligation. CIL then is about trans-national or supra-national obligation, typified in classical times by regulation of events literally 'between' (in the spaces between) states, ie on the high seas. The protection of trade across the oceans serves much the same functions as the protection of trade within national boundaries, a point which supports the Hartean deconstruction of the international-national distinction.

The trick with CIL is in its circularity; it is almost a Common Law process of 'discovering' that it's been there all along. Once discovered international tribunals will implement it in any relevant decision without further ado, and so will the courts of many countries. ${ }^{17}$ In principle, if not in empirical fact, this opens up a huge domain of international law as local/municipal law and again in a serious way erases the supposed boundaries between the two. The fact that any CIL could get incorporated into a municipal system, if shown to meet the (high) standards required to identify it as CIL in the first place, thus says that as law there is no epistemic difference between Customary International Law, and (in effect) Common Law. Lawfulness is lawfulness. Treated in this way, rather than merely an odd quirk of IL, CIL becomes a high road to the generic position as argued by Hart.

It is the notion of jus cogens or peremptory norm that provides the paradigm example of CIL as recognized. But the generally accepted examples of jus cogens are not essentially state-based. Rather, they tend to forbid certain kinds of treatment of vulnerable people eg traders besieged by pirates, a protection extended in more recent decades to civilians harmed by state officials. Of course there are often very important state links, especially in terms of pinning down culpability and hence giving some practical sense of obligation - rather than mere statements about "this sort of thing shouldn’t happen” - but, states or sovereigns are not connected in any essential way with the jus cogens. Jus cogens is centred on conduct, as of course is

\footnotetext{
17 The UK for example at least in recent decades: Trendtex Trading Corporation v Central Bank of Nigeria, [1977] QB 529.
} 
law in general: conduct and relationships, not status or level (eg State, sovereign, firm or individual citizen) which is secondary in analytic terms. And this I think is Hart's point. Customary International Law, notwithstanding its limited practical relevance at present, represents in principle a Hartean generic-style law - a law without borders.

'Sources' should therefore not have the sacrosanct status as in the standard text of international law. What is significant about 'the sources' of international law is not so much those sources as such but the fact that they are treated as sources in the practice of the International Court of Justice (ICJ). It is made clear in the Statute of the ICJ that these are what the ICJ will treat as sources, and with what relative weight etc. The whole enterprise is deliberately procedural; indeed one set of source in the ICJ Statute, termed 'universal principles,' has turned out to be entirely procedural. One possible direction in which to take Hart's account would therefore be to connect it up with other proceduralist accounts of law. Relevant approaches include that of Habermas and perhaps more concretely, that of Rawls. ${ }^{18}$

\section{CONCLUSION}

Hart was prescient in looking beyond a state-centred international law, given the subsequent and contemporary trend for this classical position to become increasingly untenable if only empirically. International law as conceived of in the orthodoxy, as a series of independent sovereign states in voluntary patterns of interaction, is found by Hart's analysis to be as inadequate as is the orthodox analysis of domestic legal obligation. Just as Hart shows that an account of municipal law in terms of 'King Rex' is inadequate (to the extent that the kingship of Rex involves being above the law etc), he by implication shows the inadequacy of an account of international law in terms of (as it were) 'Rexitania', 'Lexitania' and another hundred or more independent states - what might be called the 'Olympics' model of IL.

Sovereign states and the command theory of legal obligation stand or fall together. Hart shows clearly that the state, as usually understood, is theoretically inadequate as source or embodiment of legal command. Perhaps the state should be treated as a kind of firm (or it might be, as a large NGO, bearing in mind that NGOs can be international). That is to say, states would be thought of as entities which might have legal personality in some system, but which would coexist with, and in a sense be located at the same level of analysis as, firms. The laws affecting a state would thus be all of a kind, even though some of those laws may be 'laws governing firms [eg corporate governance] within Australia', some may be regulations concerning international firms, and some may be the relations between 'States' that we call treaties or conventions.

\footnotetext{
18 John R Morss, Crime Stories: Posnerian Pragmatism, Rawlsian Pure Procedural Justice, and the Fictional Problem, 9 DEAKIN L. REV. 643 (2004).
} 
As William Twining observes, Hart's approach is generalist - he was attempting (genuinely if not entirely successfully) to be descriptive. Twining goes on to comment that Hart was in the English positivist tradition of 'cosmopolitanism' like Bentham. Thus [Hart's] "method was of potentially very wide application, [and] his commitment was to general jurisprudence, but his focus and agenda for jurisprudence were quite narrow." ${ }^{19}$ On the basis of Hart's work, as well as other sources, Twining argues for a 'global perspective on law' that is not "naively universal[ist]." As this paper has argued, Hart's approach to international law might well contribute to the articulation of such a global perspective. If so, the jurisprudential significance of international law, with its concern for solidarity and for the common interests of the world's citizens, might at last be recognized. Duty as well as doubt comes to us across the seas.

\footnotetext{
${ }^{19}$ WiLliam Twining, GLOBALISATION AND LEgAL THEORY 48 (2000).
} 